\title{
PROTEKSI MINAT DAN BAKAT PESERTA DIDIK SELAMA PANDEMI COVID-19 DI MADRASAH ALIYAH MUHAMMADIYAH 1 MEDAN
}

Saparripin Idris, Anggie Maulidiya, Evina, Nurmuth Mainnah

STAI Sumatera, Medan

saparripinsaid@gmail.com, maulidiyaanggie@gmail.com, evina9641@gmail.com, muthmainnahnur2404@gmail.com

\begin{abstract}
Abstrack
This study aims is to analyze the protection of the interests and talents of students during the Covid-19 pandemic Madrasah Aliyah Muhammadiyah I Medan. The method used is qualitative with a descriptive study model. This research finds out how to protect and develop students interests and talents, although not directly as usual. The interests and talents of students at Madrasah Aliyah Muhammadiyah I Medan, some of the obstacles are:1) limited time, and place that does not normally take place. 2) lack of direct interaction between educators and students due to the Covid-19 pandemic. Some of the innovations that have been carried out can optimize the interests and of students, namely: 1) on-going interaction between educators and students with multimedia. 2) cooperation between parents and teachers.
\end{abstract}

Keyword : Protect, interests and talents, students, Covid-19.

\begin{abstract}
Abstrak
Tujuan penelitian ini adalah untuk menganalis tentang Proteksi Minat dan bakat peserta didik selama pandemi Covid-19 di Madrasah Aliyah Muhammadiyah I Medan. Metode yang dipakai kualitatif dengan model studi deskriptif. Penelitian ini mengetahui bagaimana cara melindungi dan mengembangkan minat dan bakat siswa walaupun tidak secara langsung seperti biasanya. Adapun hambatan dalam pengembangan minat dan bakat siswa di Madrasah Aliyah Muhammadiyah I Medan, adapun beberapa hambatannya: 1) Keterbatasan waktu, tempat yang tidak seperti biasanya berlangsung. 2) Kurangnya interaksi langsung antara pendidik dan siswa di karenakan pandemi COVID-19. Beberapa inovasi yang dilakukan dapat dioptimalkan minat dan bakat siswa ialah: 1) Berlangsungnya interaksi melalui antara pendidik dan siswa dengan multimedia. 2) Kerjasama antara orang tua dengan guru.
\end{abstract}

Kata Kunci: Proteksi, Minat, Bakat, Covid-19 


\section{A. PENDAHULUAN}

Hal penting dalam perkembangan anak yang tidak boleh dilewatkan orang tua adalah mengenai minat dan bakat anak. Mengetahui minat dan bakat anak sejak usia dini akan sangat membantu dan berguna bagi orang tua untuk membimbing mereka secara tepat. Minat dan bakat nantinya akan menjadi kecapakan hidup, yaitu kemampuan dan keberanian khusus untuk dapat bertahan hidup, tumbuh, dan menjadi berhasil, ini akan menjadi bekal yang sangat berguna dan bermanfaat kelak hingga mereka dewasa nanti.

Anak memiliki hak dan kesempatan untuk perkembangan sesuai potensinya terutama dalam bidang pendidikan. Setiap anak harusnya mendapat kesempatan, fasilitas dan pelayanan untuk mengembangkan minat dan bakatnya secara maksimal sesuai dengan kemampuan, kecerdasan, bakat, minatnya, latar belakang, dan lingkungan fisik serta sosial masing-masing siswa maka kemajuan belajar siswa yang setingkat mungkin tidak sama. (R. R. Lubis, 2018). Setiap anak memiliki minat dan bakat tersendiri, namun minat dan bakat tersebut tidak bisa langsung terlihat begitu saja. Karena itu, orang tua harus mengenali dan memahami bakat dan minat yang dimiliki anaknya. Dengan mengetahui bakat anaknya, akan lebih mudah dan terarah dalam mengembangkannya. (Fatkuroji, 2017).

Potensi bisa diartikan sebagai bakat, maupun minat siswa. Saat ini banyak remaja ataupun dewasa yang tidak tahu akan bakat, maupun minatnya. Guru tentu memiliki peran yang sangat penting untuk kemajuan dan perkembangan peserta didiknya dalam bidang pelajaran maupun perkembangan dalam bidang karakter dan kecerdasan emosionalnya.(R. R. Lubis, Irwanto, \& Harahap, 2019). Guru sebagai penyalur pembelajaran yang bertanggung jawab terhadap perkembangan siswa, alangkah baiknya dapat mengenali bakat apa yang dimiliki siswanya. Selebihnya guru berusaha untuk mengembangkan minat dan bakat yang dimiliki oleh peserta didik agar kebanyakan dilema yang terjadi di masyarakat tidak terjadi lagi.(Hasibuan \& Panjaitan, 2020).

Proses pembelajaran yang mendidik, menuntut guru harus peduli terhadap bakat dan minat siswa secara individual. Karna itu proses pembelajaran yang berbasis bakat dan minat individual siswa perlu lebih banyak diupayakan guru mata pelajaran dalam bentuk yang lebih bervariasi. Guru memiliki peran yang lebih strategis di dalam pengembangan diri siswanya (Ahmad, 2018).

Namun merebaknya kasus pandemic Covid-19 sejak awal Desember 2019. Penyakit yang menular dapat menularkan melalui bersin dan napas seseorang. Dan mengharuskan semua proses kegiatan belajar mengajar bagi peserta didik untuk beberapa waktu dilakukan di rumah. Kebijakan ini di terapkan oleh pemerintah yang mengurangi penyebaran covid-19.(Makarim, 2020). Dalam pembelajarannya, siswa dan guru dibantu dengan pembelajaran secara online. Tentunya banyak kesulitan yang dialami para guru saat menjalankan metode belajar dari rumah. Tidak sedikit pula orang tua dan siswa yang mengalami kesulitan, hal ini yang menjadi tantangan bagi guru untuk melalukan pembelajaran agar siswa terlibat secara aktif dalam belajar dan membangkitkan serta mengembangkan minat dan bakatnya. (M. Lubis, Yusri, \& Gusman, 2020) 
Dan dalam pembelajaran online, tentunya kurang efektif bagi siswa karna mereka tidak bisa menyampaikan aspirasi dalam pemikirannya. Semangat belajar pun menurun maka dari itu mereka memerlukan pendorong untuk menggerakkan siswa agar mereka mengerti dimana letak minat dan bakat mereka.

\section{Minat dan Bakat}

Bakat menurut Kamus Istilah Bimbingan dan Penyuluhan merupakan kondisi suatu kualitas yang dimiliki oleh individu, yang memungkinkan individu tersebut untuk berkembang pada masa yang akan datang (Sukardi \& Sumiati, 1993). pendapat Ngalim Purwanto bahwa bakat lebih dekat pengertiannya dengan kata Aptitude yang berarti kecakapan bawaan, yaitu yang mengenai kesanggupan (potensi-potensi) yang tertentu (Purwanto, 2007) Woodworth dan Marquis mendefinisikan bahwa: "aptitude is predictable achievement and can be measured by specially devised test". Bakat (aptitude) oleh woodworth dan Marqius dimasukkan dalam kemampuan (ability). Menurut ability mempunyai tiga arti, yaitu: (1) Achievement yang merupakan merupakan actual ability, yang dapat diukur secara langsung dengan alat atau tes tertentu. (2) Capacity yang merupakan potential ability, yang dapat diukur secara tidak langsung dengan melalui pengukuran terhadap kecakapan individu, di mana kecakapan ini berkembang dengan perpaduan antara dasar dengan training yang intensif dan pengalaman. (3) Aptitude, yaitu kualitas yang hanya dapat diungkap/diukur dengan tes khusus yang sengaja dibuat untuk itu (Suryabrata, 1989)

Dapat disimpulkan bahwa pengertian bakat adalah kemampuan atau potensi yang sudah ada pada diri seseorang dengan beberapa latihan atau keterampilan tertentu maka memungkinkan mencapai suatu kecapakan, pengetahuan dan keahlian atau keterampilan khusus, seperti bakat berhitung, bakat berbahasa dan lainnya.

Ada beberapa faktor-faktor yang turut mempengaruhi tampilnya bakat, yaitu: (1) Faktor motivasi, jika motivasi sudah bersemayam dalam diri seseorang ternyata mampu membangkitkan atau mendorong orang yang lemah menjadi lebih bergairah. Kekuatan motivasi ini akan menerjang apa saja bila ia mengkehendaki, membongkar kelemahan-kelemahan serta memporak-porandakan kemalasan yang menghinggapi. Bakat memerlukan motivasi yang sangat kuat agar mampu menunjang terwujudnya pengembangan bakat tersebut. Bakat tidak akan terlihat dan berkembang secara wajar bila tidak ada usaha dan upaya untuk mengembangkannya. Motivasilah yang menyulut untuk jadi besar atau menjadi kecil, peranan motivasi sangat menentukan. (2) Faktor nilai, faktor ini turut berperan penting dalam menentukan dapat berkembang minat dan bakatnya atau tidak. Mereka tentu memiliki pikiran tersendiri tentang bakat yang ada pada dirinya. (3) Faktor minat, Faktor minat terjadi dari perhatian yang tidak hanya berlangsung sekali dari objek yang dianggap menarik atau berharga bagi dirinya. Dengan kata lain, bahwa kecenderungan untuk menyelidiki dan manipulasi yang dilakukan oleh seseorang lama-lama akan timbullah minat. (3) Faktor kepribadian, Kepribadian atau personality memiliki pengertian yang sangat kompleks, Adler memberi pengertian gaya hidup individu, 
atau cara yang berkarakteristik mereaksinya seseorang terhadap masalah-masalah hidup, termasuk tujuan-tujuan hidup (Iskandar, 2010).

Secara bahasa minat berarti kecenderungan hati yang tinggi terhadap sesuatu (Bahasa, 1960) Dikemukakan oleh Hilgard yang dikutip oleh Slameto menyatakan "Interest is persisting tendency to pay attention to end enjoy some activity and content."Minat adalah kecendurungan yang tetap untuk memperhatikan dan mengenang beberapa kegiatan yang diminati seseorang, diperhatikan terus-menerus yang disertai dengan rasa senang (Slameto, 1987). Menurut Crow minat atau interest berhubungan dengan daya gerak yang mendorong kita cenderung atau merasa tertarik pada orang, benda, atau kegiatan (Abror, 1993) Sardiman A. M. beranggapan bahwa minat adalah suatu keadaan yang terjadi apabila seseorang melihat ciri-ciri atau arti sementara situasi yang dihubungkan dengan keinginankeinginan atau kebutuhan-kebutuhannya sendiri (A, M, 1988)

Dari ahli yang mengemukakan dapat ditarik kesimpulan bahwa minat adalah kecendurungan perasaan seseorang yang mengarah kepada suatu topik tertentu yang dinyatakan dalam berbagai tindakan karena adanya suatu perhatian, perasaan senang, tertarik pada objek tersebut.

\section{Faktor yang mempengaruhi minat dan bakat}

Untuk menumbuhkan dan mengembangkan minat dan bakat siswa tidak bisa terlepas dari pemeliharaan dan kemampuan yang dimiliki siswa. karena, untuk menjadi siswa yang memiliki minat dan bakat, tentunya harus mampu melihat minat dan bakat pada diri siswa tersebut. (Aritonang, 2008). Oleh karena itu, kita harus dapat mengetahui faktor-faktor yang mempengaruhi minat dan bakat siswa, yaitu:

a. Faktor internal

- Faktor kesehatan, kesehatan jasmani dan rohani sangat besar pengaruhnya terhadap minat dan bakat siswa, bila seseorang kesehatannya terganggu misalkan sakit pilek, demam, pusing, batuk dan sebagainya, dapat mengakibatkan cepat lelah, tidak bergairah dan tidak bersemangat untuk melakukan aktivitas.

- Cacat tubuh, adalah sesuatu yang menyebabkan kurang baik atau kurang sempurna mengenai tubuh. Cacat tubuh seperti buta, tuli, patah kaki, lumpuh dan sebagainya bisa mempengaruhi minat, siswa yang cacat minat dan bakatnya juga terganggu. Sebenarnya jika hal ini terjadi hendaknya anak atau siswa tersebut dilembagakan pendidikan khusus supaya dapat menghindari atau mengurangi kecacatannya itu.

b. Faktor psikologis

1. Perhatian Untuk mencapai hasil minat dan bakat yang baik, maka siswa harus mempunyai perhatian terhadap bahan yang dipelajarinya, jika bahan atau materi pelajaran tidak menjadi perhatian siswa, maka minat dan bakat yang timbul pun akan rendah, jika begitu akan timbul kebosanan, siswa tidak bergairah, dan bisa jadi siswa tidak lagi suka dengan bahan yang dipelajarinya. Agar siswa berminat dan berbakat, usahakanlah bahan atau materi pelajaran selalu menarik perhatian, salah satunya usaha tersebut 
adalah dengan menggunakan variasi gaya mengajar yang sesuai dan tepat dengan materi pelajaran.

2. Kesiapan, menurut Kesiapan ini perlu diperhatikan dalam proses belajar mengajar, seperti halnya jika kita mengajar ilmu filsafat kepada anak-anak yang baru duduk di bangku sekolah menengah, anak tersebut tidak akan mampu memahami atau menerimanya.

3. Bakat atau intelegensi, bakat adalah kemampuan untuk belajar. Kemampuan itu baru akan terealisasi menjadi kecakapan yang nyata sesudah belajar, misalkan orang berbakat menyanyi, suara, nada lagunya terdengar lebih merdu disbanding dengan orang yang tidak berbakat menyanyi. Bakat bias mempengaruhi belajar, jika bahan pelajaran yang dipelajari siswa sesuai dengan bakat, maka siswa akan berminat terhadap pelajaran tersebut, begitu juga intelegensi, orang yang memiliki intelegensi (IQ) tinggi, umumnya mudah belajar dan hasilnyapun cenderung baik, sebaliknya jika seseorang yang "IQ" nya rendah akan mengalami kesukaran dalam belajar. Jadi kedua aspek kejiwaan ini besar sekali pengaruhnya terhadap minat belajar dan keberhasilan belajar. Bila seseorang memiliki intelegensi tinggi dan bakatnya ada dalam bidang yang dipelajari, maka proses belajarnya akan lancar dan sukses disbanding dengan orang yang memiliki "IQ" rendah dan berbakat, kedua aspek tersebut hendaknya seimbang, agar tercapai tujuan yang hendak dicapai.

c. Faktor eksternal

Faktor keluarga Minat dan bakat siswa bisa dipengaruhi oleh keluarga seperti cara orang tua mendidik, suasana rumah dan keadaan ekonomi keluarga. Akan diuraikan sebagai berikut: a) Cara orang tua mendidik Cara orang tua mendidik anaknya sangat besar pengaruhnya terhadap belajar anak. Hal ini dipertegas oleh Sutjipto Wirowidjojo yang menyatakan bahwa keluarga adalah lembaga pendidikan yang pertama dan utama. Jika orang tua tidak memperhatikan pendidikan anaknya (acuh tak acuh terhadap belajar anaknya) seperti tidak mengatur waktu belajar, tidak melengkapi alat belajarnya dan tidak memperhatikan apakah anaknya belajar atau tidak, semua ini berpengaruh pada semangat belajar anaknya, bias jadi anaknya tersebut malas dan tidak bersemangat belajar. Hasil yang didapatkannya pun tidak memuaskan bahkan mungkin gagal dalam studinya. Mendidik anak tidak baik jika terlalu dimanjakan dan juga tidak baik jika mendidik terlalu keras. Untuk itu, perlu adanya bimbingan dan penyuluhan yang tentunya melibatkan orang tua, yang sangat berperan penting akan keberhasilan bimbingan tersebut. b) Suasana rumah Suasana rumah dimaksudkan adalah situasi atau kejadian-kejadian yang sering terjadi di dalam keluarga, dimana anak berada dan belajar. Suasana rumah yang gaduh, ramai dan semrawut tidak memberi ketenangan kepada anaknya yang belajar. Biasanya ini terjadi pada keluarga yang besar dan terlalu banyak penghuninya, suasana rumah yang tegang, ribut, sering cekcok, biasa menyebabkan anak bosan di rumah, dan sulit berkonsentrasi dalam belajarnya. 


\section{Hubungan Antara Minat dan Bakat}

Hubungan antara minat dan bakat sangat berpengaruh terhadap kesuksesan dari potensi yang dimiliki oleh peserta didik. Hubungan antara keduanya bagaikan simbiosis mutualisme yang saling menguntungkan satu sama lain. Minat dan bakat dapat dibentuk menjadi yang lebih baik dan sempurna, sehingga minat dan bakat dapat dikembangkan menjadi sesuatu yang istimewa.

Setiap peserta didik memiliki minat dan bakat yang berbeda-beda, tergantung bagaimana siswa tersebut mengembangkan minat dan bakat yang mereka miliki. Peserta didik harus mampu memanfaatkan minat dan bakat yang dimilikinya agar tercipta potensi yang terbentuk menjadi sebuah kemampuan dan sebuah keberhasilan.

Minat adalah faktor pendukung bagi pengembangan bakat karena tanpa minat, bakat tidak akan berguna, dan sebaliknya pula bakat tanpa minat akan sulit untuk mengembangkannya. Seorang siswa harus mengetahui dan mengenali bakat dan minatnya begitupun guru harus bisa dan tahu bagaimana cara mengembangkan minat dan bakat siswanya.

Tujuan mengembangkan minat dan bakat, yaitu agar siswa di Madrasah aliyah Muhammadiyah I Medan dapat belajar dan bekerja di bidang yang sesuai dengan kemampuan bakat dan minat yang dimilikinya. Maka, ikatan antara keinginan dan bakat tidak akan berkembang dengan baik apabila tidak didukung dengan minat yang tinggi. Dengan demikian minat dan bakat merupakan faktor yang saling mempengaruhi satu sama lain.

Penelitian ini dilaksanakan di Madrasah Aliyah Muhammadiyah I Medan beralamat jalan Mandala By Pass No. 140, Bantan, Kec. Medan Tembung, Kota Medan, Sumatera Utara. Alasan untuk memilih lokasi penelitian ini karena sesuai dengan kriteria judul yang telah kami rangkum bersama. Adapun yang menjadi objek penelitiannya adalah guru-guru di sekolah Madrasah Aliyah Muhammadiyah I Medan sebanyak dua orang. Mengapa begitu sedikit? Dikarenakan saat ini kota, Negara, dan belahan dunia sedang mengalami musibah wabah Covid-19. Maka pihak sekolah membatasi guru untuk kami wawancarai karena social distancing.

\section{B. METODE}

Penelitian ini menggunakan metode kualitatif dengan pendekatan studi deskriptif. Penelitian ini dilaksanakan di Madrasah Aliyah 1 Medan. Penelitian ini dilaksanakan dari bulan Mei sampai dengan bulan Oktober 2020. Dalam pengumpulan data ada beberapa metode yang dipergunakan, yaitu: (1) Wawancara: Untuk mendapatkan informasi yang lebih akurat peneliti melalukan wawancara dengan beberapa guru yang ada di sekolah Madrasah Aliyah Muhammadiyah I Medan untuk mengetahui masalah yang dihadapi dan pemecahannya. Metode ini juga ditunjukkan kepada beberapa responden untuk memperoleh data tentang kendala belajar minat dan bakat online yang mereka alami selama pandemi Covid-19 saat ini. (2) Observasi: Kegiatan ini ialah mengamati dan bagaimana cara dari beberapa guru di sekolah 
Madrasah Aliyah Muhammadiyah 1 Medan. Dalam hal melindungi dan mengembangkan minat dan bakat siswanya serta mengumpulkan informasi atau data yang mudah dipahami dan diamati secara langsung yaitu proses belajar mengajar minat dan bakat online.

Sumber data dari penelitian ini terbagi menjadi dua, yaitu sumber data primer dan sumber data sekunder. Sumber data primer, maksudnya ialah sumber data utama, yang diperoleh langsung dari narasumber utama peneliti. Narasumber utama dalam penelitian ini ialah guru bidang kesiswaan di sekolah Madrasah Aliyah Muhammadiyah I Medan. Sumber data sekunder adalah sumber data pendukung, yang diperoleh dari semua yang berkaitan dengan narasumber utama, seperti pemakaian media, kemampuan guru di bidang ITE, materi, sarana dan prasarana (M. Lubis et al., 2020)

\section{HASIL DAN PEMBAHASAN}

Guru memiliki peranan sangat penting dalam perkembangan minat dan bakat siswanya. Sebab, gurulah motivator utama bagi siswa dalam minat dan bakatnya. Banyak siswa yang tidak dapat menyalurkan minat dan bakat mereka karena kurangnya pendekatan antara guru dengan siswa. Apalagi merebaknya kasus pandemi Covid-19 yang mengharuskan siswa melakukan pembelajaran dari rumah. Bagaimana dan cara apa yang bisa membuat guru mengembangkan minat dan bakat siswa selama pandemi Covid-19.

\section{Pengembangan Minat dan Bakat Siswa di Madrasah Aliyah 1 Medan}

Menurut persepsi guru di sekolah Madrasah Aliyah Muhammadiyah I Medan mengenai minat dan bakat siswa, bahwa mereka seorang pendidiklah yang harus lebih memperhatikan, terhadap perkembangan anak didiknya. Dan peran guru seorang pendidik di sekolah terlebih lagi saat masa pandemi seperti sekarang ini, harus bekerjasama dan berkomunikasi kepada orang tua dirumah yang dimana mengenai hal minat dan bakat anak.

Menurut guru Madrasah Aliyah Muhammadiyah I Medan mengenai minat dan bakat siswa, bahwa seorang pendidik harus mampu menjelaskan nilai-nilai minat dan bakat yang terkandung dalam materi yang guru ajarkan, sehingga para siswa yakin dengan minat dan bakat tersebut semakin kuat dan kelak ia akan mengembangkan dan mengaplikasikannya dalam situasi yang relevan (Syah, 2009).

Persepsi tentang minat dan bakat siswa ini memang memberikan arti penting dalam peeningkatan minat dan bakat siswa. Sebab bagi guru yang merasa bahwa minat dan bakat adalah sesuatu yang menunjang keberhasilan belajar, maka sang guru akan memberikan perhatian lebih kepada hal tersebut. Oleh karena itu kadang kala tidak sedikit guru di temui tidak ingin memperhatikan minat dan bakat anaknya.

Mengembangkan dan menyalurkan minat dan bakat siswa seperti yang di minati peserta didik. Hal itu dapat kita ketahui dengan menggunakan media yang menarik untuk mencuri perhatian para siswa. Setiap guru pasti memiliki cara dan metode yang berbeda-beda dalam mengetahui minat dan bakat para siswanya. Agar tersalurnya minat dan bakat anak nantinya perlu kita lihat kemampuan siswa itu 
sendiri apakah dia ahli dibidang olahraga, atau ahli dibidang seni. Untuk itu para guru harus lebih memperhatikan dimana minat dan bakatnya. Supaya kedepannya siswa tidak salah dalam mengambil langkah. Dan selaku orang tua harus mendukung minat dan bakat anak.

Guru harus bisa terlebih dahulu melihat bakat siswa yang tentunya berbedabeda. Untuk mendapati bakat tersebut, guru harus mengamati dan mengawasi satu persatu peserta didik dari awal kegiatan belajar mengajar, dan melihat dalam bidang manakah peserta didik tersebut lebih menonjol baik akademik maupun non akademik. Setelah mengetahui bidang tersebut, siswa di bimbing untuk lebih mendalami bakat tersebut, hingga bakat tersebut bisa menunjang prestasi siswa.

Pasti ada kesulitan bagi guru-guru sebagai seorang pendidik, untuk mengetahui minat dan bakat anak apalagi dimasa COVID-19 ini. Sudah tidak seperti sebelumnya, kita melihat secara langsung kemampuan-kemampuan anak didik kami, melihat dengan nyata apa saja yang mereka gemari, tetapi karena masa Covid-19 ini tak jarang keluhan yang kami dapati dari siswa-siswa kami dan orang orang tua dari anak-anak. Solusi yang kami berikan kepada anak didik kami, yaitu:

a. Membantu anak dalam mengenal bakat yang ada pada dirinya

b. Memberikan pengetahuan tentang bakat

c. Meningkatkan motivasi anak untuk mengembangkan dan melatih bakatnya.

d. Memfasilitasi sarana bagi pengenbangan bakat

e. Memberikan kesempatan untuk mengikuti lomba-lomba sesuai bakat yang dimiliki anak.

\section{Proteksi minat dan bakat siswa di Madrasah Aliyah 1 Medan}

Ada beberapa hal yang dilakukan di madrasah aliyah 1 medan untuk melindungi minat dan bakat siswa sehingga tidak berdampak signifikan terhadap hasil pembelajaran, terutama pada masa pendemi Covid-19. Beberapa hal yang dilakukan untuk melinungi minat dan bakat siswa tersebut sebagaimana di jelaskan di bawah ini:

a. Menjaga stimulus siswa baik secara internal maupun eksternal. Dan mengingatkan kepada para peserta didiknya, untuk tetap meningkatkan minat yang mereka gemari maupun kemampuan bakat yang mereka punya.

b. Guru mengarahkan, menjaga, dan membimbing agar siswa tumbuh dan berkembang sesuai dengan potensi, minat dan bakatnya.

c. Guru juga membangkitkan motivasi peserta didik agar mereka selalu semangat belajar dan semangat dalam mengembangkan minat dan bakatnya.

Hasil dari penelitian mengenai proteksi minat dan bakat siswa selama pandemi Covid-19 di Madrasah Aliyah Muhammadiyah I Medan. Dalam usaha pengembangan minat dan bakat anak, guru hendaknya memberikan kesempatan yang sama kepada seluruh siswa untuk mengembangkan segala potensi yang ada pada dirinya. Namun, kendala guru yang dihadapi ialah proses pembelajaran dari rumah yang mengharuskan guru untuk tetap melindungi dan mengembangkan minat dan bakat siswanya. Dan bagaimana guru menyalurkan minat dan bakat siswanya dalam pembelajaran dari rumah selama pandemic. 


\section{SIMPULAN}

Semakin berkembangnya wabah Covid-19 memang memberikan dampak tersendiri pada dunia pendidikan, terutama pada interaksi dan pola pemberajaran. Pembelajaran memang dapatlah dilakukan dengan kondisi apapun, namun tentu hasil tidak akan seefisien pembelajaran yang dilakukan dengan cara tatap muka secara langsung di dalam kelas. Tentu juga akan terasa sulit bagi seorang pendidik untuk mengetahui kemampuan minat dan bakat siswanya. Untuk mengoptimalkannya tentu banyak cara yang dilakukan oleh seorang pendidik. Adapun beberapa inovasi yang dilakukan untuk mengetahui kemampuan minat dan bakat anak ialah: Berlangsungnya interaksi melalui antara pendidik dan siswa dengan multimedia, Kerjasama antara orang tua dengan guru, Pembelajaran secara daring selama masa pandemi Covid-19 juga memiliki hambatan dalam pengembangan minat dan bakat siswa di Madrasah Aliyah Muhammadiyah I Medan, adapun beberapa hambatannya: Keterbatasan waktu, tempat yang tidak seperti biasanya berlangsung. Kurangnya interaksi langsung antara pendidik dan siswa di karenakan pandemi Covid-19.

\section{DAFTAR PUSTAKA}

A, M, S. (1988). Interaksi dan Motivasi Belajar Mengajar. Jakarta: CV. Rajawali. Abror, A. (1993). Rahman, Psikologi Pendidikan, Yogyakarta: PT. Tiara Wacana.

Ahmad, S. (2018). Bimbingan dan Konseling di Sekolah, Komsep, Teori, dan Aplikasinya. Jakarta: Prenadamedia Group.

Aritonang, K. T. (2008). Minat dan motivasi dalam meningkatkan hasil belajar siswa. Jurnal Pendidikan Penabur, 7(10), 11-21.

Bahasa, T. P. K. P. P. dan P. (1960). K. In Kamus Besar Bahasa Indonesia. Jakarta.

Fatkuroji, F. (2017). Implementasi Kebijakan Pembelajaran Terpadu dan Minat Pelanggan Pendidikan. Tarbawi: Jurnal Keilmuan Manajemen Pendidikan, 2(02), 28-40.

Hasibuan, H. R., \& Panjaitan, R. W. (2020). Pemikiran Ibnu Qoyyim tentang Proteksi Minat dan Motivasi Belajar dalam Kitab Ad-daa'wa Ad-dawaa'. Fitrah: Journal of Islamic Education, 1(1), 55-71.

Iskandar, H. (2010). Tumbuhkan Minat Kembangkan Bakat. Bandung: ST Book.

Lubis, M., Yusri, D., \& Gusman, M. (2020). Pembelajaran Pendidikan Agama Islam Berbasis E-Learning (Studi Inovasi Pendidik MTS. PAI Medan di Tengah Wabah Covid-19). Fitrah: Journal of Islamic Education, 1(1), 1-15.

Lubis, R. R. (2018). Optimalisasi Kecerdasan Spiritual Anak. Jurnal Al-Fatih, 1(1), 1-18.

Lubis, R. R., Irwanto, I., \& Harahap, M. Y. (2019). Increasing Learning Outcomes and Ability Critical Thinking of Students Through Application Problem Based Learning Strategies. International Journal for Educational and Vocational Studies, 1(6), 524527.

Makarim, N. anwar. Surat Edaran Mendikbud No. 4 Tahun 2020 tetang Pelaksanaan Kebijakan Pendidikan dalam Masa Darurat Penyebaran Covid-19. , (2020).

Purwanto, N. (2007). Psikologi pendidikan dengan pendekatan Baru Edisi Revisi. Bandung: PT Remaja Rosda Karya. 
Slameto. (1987). Belajar dan Faktor-Faktor Yang Mempengaruhi. Jakarta: Rineka Cipta.

Sukardi, D. K., \& Sumiati, D. M. (1993). Kamus istilah bimbingan dan penyuluhan. Usaha Nasional.

Suryabrata, S. (1989). Psikologi Pendidikan. Bandung: Remaja Rosdakarya.

Syah, M. (2009). Psikologi Belajar. Jakarta: PT. Raja Grafindo Persada. 